\title{
Regional priorities of the Eastern energy policy of Russia
}

\author{
Boris Saneev ${ }^{*}$, Melentiev Energy Systems Institute of Siberian Branch of the Russian \\ Academy of Sciences, Irkutsk, Russia
}

\begin{abstract}
The paper describes the features of Russia's economic development in a new economic environment, which have necessitated a revision of priorities in the energy policy. The initial conditions, targets and strategic directions of the energy sector development in the East of the country are given. The priority directions of innovation-technology cooperation of Russia with the countries of Northeast Asia in the energy sphere are shown, and proposals are made for a list of necessary conditions and initiatives for their successful implementation
\end{abstract}

\section{Eastern vector - a priority direction of the energy development in Russia in the first half of the 21st century (basic concepts)}

Specific features of the economic development of Russia in a new economic environment have caused the need to revise the previously adopted priorities in its economic and energy policy.

Russia's national interests necessitate the intensification of its mutually beneficial energy cooperation with China, Japan, Korea and other countries of East and Northeast $\operatorname{Asia}^{1}[1,2]$.

This priority direction of the country's energy development was called in official documents "Eastern vector of the energy policy of Russia" [3, 4], the essence of which, conceptually, can be summarized as follows:

- creation of new energy centers in the East of the country ${ }^{2}$ will contribute to enhancing the energy security of Russia, restoring and strengthening the broken fuel and energy ties among the regions, solving many important tasks of the federal, interregional and regional levels;

- creation of a developed energy infrastructure in the form of interstate gas and oil pipelines, transmission lines in Eastern Russia and Northeast Asia will reduce the cost of energy carriers, improve the reliability of energy and fuel supply to consumers in different countries, and facilitate the solution of environmental problems.

\footnotetext{
* Corresponding author: saneev@isem.irk.ru

${ }^{1}$ According to the foreign publications and some official documents of Japan, China and Republic of Korea the countries of Northeast Asia (NEA) are Mongolia, China, North and South Korea, Japan.

${ }^{2}$ In the Energy Strategies of Russia-2020, 2030 the East of the country includes the regions of East Siberia and the Far East.
} 
The Eastern energy policy of Russia, being part of the economic policy, is not an end in itself, but a tool for solving many crucial federal, interregional and regional tasks:

1. Social-economic and geopolitical tasks:

- social - to improve the comfort, style and quality of population life in the eastern regions of Russia;

- economic - to enhance the efficiency of the economy of Russia' East and its competitiveness, increase the availability of resources in the country and accessibility of remote territories, expand the active economic space of Russia, create the conditions for attraction of foreign investment and advanced technologies;

- political - to consolidate and integrate the entities of the Federation, strengthen the unity of the economic and energy space of the country;

- geopolitical - to strengthen Russia's positions in the world economic system, in the community of Central and Northeast Asia.

\section{Energy tasks:}

- to increase the energy security of the country and regions;

- to increase the adaptability and reliability of energy and fuel supply to consumers;

- to improve the territorial-production structure of the energy sector in the country and especially its eastern regions;

- to build the energy-transport infrastructure in the East of Russia (oil and gas pipelines, transmission lines) and create a unified energy-transport space in Russia.

The eastern regions of the country - East Siberia and the Far East - with their great economic and energy potential are of paramount significance for the implementation of Russia's national interests in this strategically important region of the world.

Currently, Russia has completed a complex and time-consuming phase of work on the formation of a large number of policy documents defining the strategic development of the economy and energy in the East of the country until 2030 in the context of energy cooperation between Russia and the countries of Northeast Asia: "Energy Strategy of Russia-2030 "[4], "Program for creation of a unified gas production, transportation and supply system in East Siberia and the Far East, considering potential gas export to the markets of China and other APR countries [5], "Strategy of socioeconomic development of the Far East and Baikal region 2025" [6], "Strategy of socioeconomic development of Siberia 2020"[7] and others.

The Energy Systems Institute of SB RAS makes a certain contribution to generation of the Eastern energy strategy of Russia. In 2007-2014 the Institute carried out a vast series of studies on justification of long-term trends in energy sector development of the country and its eastern regions and some RF entities in their territories within the framework of works on justification of the Energy Strategy of Russia-2030 and by order of the regional authorities [8-13].

The strategy of long-term energy sector development for East Siberia and the Far East was generated in terms of some initial conditions and targets, the following two of them being most important.

1. In the next 15-20 years, Russia will be unable to intensively develop vast spaces of East Siberia and the Far East. Hence, it is important to strengthen the base of future development, which can be achieved by implementing the so called strategic scenario of the economy development in these regions.

The strategic scenario of the economy development in the eastern regions suggests that the economy of Russia and its eastern regions should approach the modern average European level both qualitatively and quantitatively. At the same time, the rates of economic growth in the regions under consideration should be higher than the average for Russia. It is also envisaged to increase the share of these regions in the total population of the country. 
2. In the considered future the energy development in East Siberia and the Far East will be focused on both satisfaction of domestic demand for energy carriers and export of Russian fuel and energy resources to the energy markets of Northeast Asia.

Analysis of the energy market conditions in China, Korea, Japan and other countries of Northeast and East Asia shows that in these countries there is a niche for Russian energy resources and Russia is ready to supply energy resources from the eastern regions to these countries under mutually acceptable terms in the following volumes $[4,8,14]$ : oil-from 69 million t in 2016 up to 75-80 million t in 2030; natural gas - from 15 billion $m^{3}$ in 2016 up to 50-60 billion $\mathrm{m}^{3}$ in 2030; coal - from 70 million $t$ in 2016 up to 75-85 million $t$ in 2030; electrical energy - from 3.6 billion $\mathrm{kWh}$ in 2016, up to 45-50 billion $\mathrm{kWh}$ in 2030.

The Russian government, regional authorities and companies have started a large-scale development of energy resources in the East of the country.

At present several large fuel and energy projects aimed at markets of Northeast Asia form the material base of the eastern vector of Russia's energy policy:

First, construction of the oil pipeline "East Siberia - Pacific Ocean" with a capacity of 80 million $\mathrm{t} /$ year with an oil pipeline branch to Skovorodino towards China with a capacity of up to 15-20 million t/year.

Second, elaboration by "Gazprom" of a program on the development of natural gas resources in the East of Russia, conversion of Russian regions to natural gas and natural gas delivery to NEA countries

Third, studies carried out by the Russian generation companies on the possibility of large-scale electricity supply to China, Japan and to other NEA countries.

In the context of new global and regional challenges, it is critical for Russia to pursue an active innovation-technology policy in parallel with the trade in energy resources in its cooperation with NEA countries.

\section{Priority directions of innovation-technology cooperation between Russia and NEA countries in the energy sphere}

\subsection{Participation in construction of new petroleum and gas chemical clusters in Russia and in their joint management}

Speaking about the oil and gas cooperation between Russia and NEA countries, the following factors must be taken into consideration.

1. At present in Russia at all levels, there is a clear understanding of the need to supply international markets not only with raw hydrocarbons, but also with products of their deep conversion, with a high added value. To this end, in the eastern regions of Russia it is proposed to increase the production of petroleum products, create new specialized industries - petroleum and gas chemical industries, because the demand for their products in Russia, in the world and in the countries of Northeast Asia is large enough. In the future, Russia may become the largest exporter of polymer products in the region.

2. As is known, the oil and gas fields of the Siberian platform are unique in their helium and ethane content. For example, the natural gas fields of the Siberian platform contain 0.3$0.5 \%$ helium and $4.6-7.2 \%$ ethane. Helium reserves $\left(\mathrm{C}_{1}+\mathrm{C}_{2}\right.$ categories $)$ on the Siberian platform are estimated at 8.5 billion $\mathrm{m}^{3}$, or about $30 \%$ of world reserves.

In the future Russia may become the largest helium exporter.

The Ministry of Energy of Russia worked out the plan of petroleum and gas chemistry development in Russia until 2030, which was approved by the order No.79 of the Ministry of Energy, of March 1, 2012 [15].

The plan provides for the creation of 6 petroleum and gas chemical clusters in Russia by 2030: 
- Northwestern

- Caspian

- Volga

- West Siberian

- East Siberian

- Far Eastern

Russia is interested in fruitful cooperation with foreign companies in the formation of new petroleum and gas chemical clusters in the East of the country and in the joint sale of polymer products in the Russian and foreign markets.

\subsection{Participation in creation of interstate power pools in NEA}

\section{(1) General look at the problem}

The interstate integration and cooperation of Russia with the countries of Northeast Asia in the field of electric power industry is one of the components of the Eastern energy strategy of the Russian Federation.

This cooperation implies the development of interstate electrical ties of the eastern regions of Russia with the "neighboring" countries: Mongolia, China, Japan, North and South Korea.

The case in point is the possible integration of the power systems of Eastern Russia (East Siberia and the Far East), Mongolia, China, North and South Korea, and Japan for parallel operation.

Such an interstate power super pool can include different types of power plants (thermal, hydro, nuclear, wind, etc) with a total installed capacity of above 500 million $\mathrm{kW}$.

\section{(2) Creation of interstate power pools in NEA: prospects for Russia}

A large electric power base of the country has been created in East Siberia and the Far East: over $20 \%$ of the capacity of all Russian power plants is installed in these regions. According to various estimates, the quickly realized export electric power potential of the eastern regions is $10-15$ million $\mathrm{kW}$, including 6-7 million $\mathrm{kW}$ in East Siberia and 4-8 million $\mathrm{kW}$ in the Far East.

Calculations show that the reconstruction of existing power plants, the completion of those under construction and the commissioning of new power plants planned for construction in the near future only in East Siberia will make it possible to have a large excess of electric power (according to various estimates from 30 to 40 billion $\mathrm{kWh}$ ).

Such a volume of electric power can be transmitted via high voltage transmission lines both to the south-east direction (Mongolia, China) and to the Russian Far East. The construction of the high voltage transmission line East Siberia - the Far East will integrate the interconnected power systems of Siberia and the Far East for parallel operation, which will improve the reliability of electricity supply to consumers in these regions and create the necessary prerequisites for the formation of the Eastern wing of global world power system $[16,17]$.

Currently, Russian companies are studying the possibility of constructing exportoriented power plants and high voltage transmission lines in Russia jointly with foreign companies for large-scale electric power exports (in the amount of 60-70 billion $\mathrm{kWh}$ ) from the eastern regions of Russia to China, 20-25 billion $\mathrm{kWh}$ to the Republic of Korea, 25-30 billion kWh to Japan. Russia and China can actively and fruitfully cooperate with Mongolia in the formation of the interstate power system Russia-Mongolia-China [18].

Russian generation companies, research and design institutes actively participate in the development of the concept of forming the Asian supergrid [19]. 
Russia can actively and effectively cooperate with Mongolia in the formation of Gobitec and utilization of its sun and wind potential for the creation of the Asian supergrid [20].

\subsection{Innovation-technology cooperation in the coal sphere}

\section{Cooperation in the integrated and deep processing of brown coals}

A promising direction of innovation-technology cooperation between Russia and NEA countries in the coal sphere is the creation of joint ventures for the integrated and deep processing of Russian brown coals and thereby, the creation of a new specialized branch in the form of coal chemical production clusters in Eastern Russia in the future.

The brown coal reserves in East Siberia and the Far East amount to more than 85 billion tons [21]. The largest brown coal deposits include:

- deposits of the Kansk-Achinsk basin in the Krasnoyarsk Territory;

- Svobodninskoye and Sergeevskoye deposits in the Amur Region:

- Kangalasskoye in the Sakha Republic (Yakutia);

- Ushumskoye in the Jewish Autonomous Region;

- Mukhinskoye in the Khabarovsk Territory;

- Solntsevskoye in the Sakhalin Region.

Owing to the relatively low costs on coal mining, it is advisable to create joint ventures with foreign companies for the integrated and deep processing of brown coals in the future on the basis of these deposits.

The products of deep coal processing (primarily motor fuel) can be supplied to Russian and foreign consumers.

\subsection{Cooperation in reliable energy supply to isolated and hard-to-reach consumers of the eastern regions of Russia owing to renewable energy}

The draft of the Energy Strategy of Russia-2035 [22] for this period provides for largescale use of renewable energy sources: an increase in the share of renewable energy sources in total electric power production from $0.2 \%$ at present to $3 \%$ in 2035 . This is especially important for the economy of the eastern regions.

The use of renewable energy sources (mini-hydro, geothermal, solar and wind power plants) is the strategic priority for the energy development in the northern and hard-to-reach areas of Eastern Russia.

The total capacity of renewable energy sources commissioned in the areas of decentralized and unstable power supply in the eastern regions of the Russian Federation in the period up to 2035 is estimated at $600-870$ MW under the base and moderately optimistic scenarios, respectively [23]. The main share in the capacity of commissioned renewable energy sources in East Siberia is due to solar power plants (287-318 MW). In the regions of the Far East, the wind power plants (84-155 MW) form the main share in the structure of commissioned capacities. By 2035 the total installed capacity of renewable energy sources in the eastern regions will increase by 5.5-7.5 times and will be 727-1000 MW, of which solar power plants - 335-385 MW, wind power plants - 100-210 MW.

The Kamchatka Territory, the Kuril Islands of the Sakhalin Region, the Arctic coast of the Krasnoyarsk Territory and the Sakha Republic (Yakutia), the eastern part of the Magadan Region, the Khabarovsk and Primorsky Territories, and the northeast of the Chukotka Autonomous Region are the most promising areas for wind energy development in the East of Russia.

The Republics of Buryatia, Tyva, Khakassia, Sakha (Yakutia), the Trans-Baikal Territory, and the southern areas of the Irkutsk and Amur Regions are strategic for solar energy development. 
The fruitful cooperation with foreign companies can be expected in the field of construction of renewable energy sources and creation of joint ventures in the eastern regions of Russia.

Joint projects with the Japanese companies Komaihaltec Inc. and MITSUI \& CO., LTD. for the construction of wind power plants in the urban-type settlement of Ust-Kamchatsk, Kamchatka Territory and the urban-type settlement of Tiksi, Sakha Republic (Yakutia) can serve as an example of such cooperation.

\section{Conclusions}

1. Implementation of Russia's Eastern energy strategy is a very difficult problem. Its complexity lies in the fact that it is interdisciplinary in nature, is implemented on a vast territory, involves a large number of Russian and foreign participants; the policy measures (especially interstate fuel and energy projects) are very capital intensive and their implementation suggests close international energy cooperation of the countries at the federal (state), interregional and regional levels.

2. There is a need to develop a scientifically based strategy (roadmap) for energy cooperation between Russia and the countries of Northeast Asia, which should show the order of development of fuel and energy resources, the order and time stages of their supply to own consumers, the volumes of export-import supplies. It should also assess the socioeconomic and other consequences of the implementation of specific interstate projects not only for individual companies, but also for the regions and the country as a whole.

3. To promote mutually beneficial forms of cooperation between Russia and NEA countries in the energy sphere, it is necessary to fulfill at least the following five conditions:

1) Availability of the political will and the serious intentions of the participants to realize a specific energy project that is mutually beneficial for each country.

2) Coordination of the economic and energy policies of the central, regional authorities and business of the countries in developing the interstate energy projects.

3) Fulfillment of the integrated, system assessment of the consequences (effects) for countries, regions, energy companies of the implementation of large interstate energy projects.

4) Development of the mutually acceptable mechanisms for implementation of the interstate energy projects (organizational, economic, legal and other mechanisms),

5) Development and implementation of the interstate projects by an international team (at all stages: from the feasibility study and design works to their practical implementation).

\section{References}

1. Study on comprehensive energy plan in East Siberia and the Far East of the Russian Federation. The Energy Research Institute of the Russian Academy of Sciences, Siberian Energy Institute of SB RAS, The Institute of Energy Economics, Japan. Executive Summary. First Phase, 53 p. (March, 1994), Second Phase, 141 p. (September 1995)

2. A.A. Makarov. World energy and Eurasian energy space. M.: Energoatomizdat, 280 p. (1998)

3. Russia's energy strategy 2020, (approved by the resolution of the Government of RF No. 1234-p of August 28, 2003). 118 p., Moscow (September 2003)

4. Russia's energy strategy 2030 (approved by the resolution of the Government of RF No.1715-p of November 13 2009). http://www.energystrategy.ru/projects/es-2030.htm 
5. Program for creation of unified gas production, transportation and supply system in East Siberia and the Far East, considering potential gas export to the markets of China and other APR countries (approved by the order No. 340 of Ministry of Industry and Energy of RF of 03.09.2007)

6. Strategy for socioeconomic development of the Far East and Baikal region 2025 (approved by the resolution of the Government of RF No.2094-p of December 28, 2009) http://www.minregion.ru/activities/territorial_planning/strategy/federal_development/34 6/

7. Strategy of socioeconomic development of Siberia 2020 (approved by the resolution of the Government of RF No.1120-p of July 5 2010)

8. Eastern vector of Russia's energy strategy: current state, look into the future. Ed. by N.I. Voropai, B.G. Saneev. Novosibirsk: Academic Publishing House "Geo", 368 p. (2011)

9. Fuel and energy complex of the Sakhalin region: current state and development prospects. Ed. by B.G. Saneev, V.N. Tikhonkikh. Moscow: Publishing House "Energia", 240 p. (2010)

10. Fuel and energy complex of the Amur region: current state and development prospects /Ed.by B.G. Saneev, V.E. Peskov. Moscow: Publishing House "Energia", 240 p. (2010)

11. Energy strategy of the Republic of Sakha (Yakutia) 2030. Ed. by G.F. Alekseyev, V.I. Kondratieva, A.A. Struchkov, N.A. Petrov, B.G. Saneev, A.F. Safronov. YakutskIrkutsk: Media-Holding "Yakutia", 328 p. (2010)

12. Fuel and energy complex of the Irkutsk region. Current state, development prospects / Ed. by B.G. Saneev, P.A. Voronin. Moscow: Publishing House "Energia", 230 p. (2013)

13. Energy sector of the Baikal region: current state, prospects, development strategy/Ed. by B.G. Saneev. Novosibirsk: Academic Publishing House "Geo", 176 p. (2015)

14. A.A. Makarov, N.I. Voropai, V.V. Saenko, B.G. Saneev, et al. Regional features of fuel and energy complex, in the book "Russia's energy: look into the future". Materials for the energy strategy of Russia 2030. Ed. by A.B. Yanovsky et al. M. Publishing House "Energiya", pp.435-460. (2010)

15. Plan for the development of gas and petro chemistry in Russia until 2030 (stage II), approved by the order of the Ministry of Energy of Russia No.79, (March 1, 2012)

16. N.I. Voropai, V.V. Ershevich, Y.N. Rudenko Development of international power interconnections - a way to the creation of global electric power system. Irkutsk: SEI SB RAS, 29 p. (preprint) (1995)

17. L.S. Belyaev, S.V. Podkovalnikov, V.A. Saveliev, L.Y .Chudinova. Effectiveness of interstate electric ties. Novosibirsk: Nauka, 239 p. (2008)

18. N.I. Voropai, B.G. Saneev, S. Batkhuyag, Kh. Enkhjargal. Energy cooperation between Mongolia and Russia: current state and strategic directions. Khabarovsk: Spatial economics, No.3, pp.108-122. (2013)

19. N.I. Voropai, S.V. Podkovalnikov, B.G. Saneev. Interstate cooperation in Northeast Asia: state, potential projects, energy infrastructure. Moscow: Energy policy, No.2, pp.55-64. (2014)

20. Gobitec and Asian Supergrid for Renewable Energies in Northeast Asia / S. Mano, B. Ovgor, Z. Samadov, D. Sokolov, B. Saneev, etc. Brussels, 110 p. (2014)

21. Program for the coal industry development in Russia 2030 /Ministry of Energy of the Russian Federation, Moscow, 178 p. (2014)

22. Draft energy strategy of the Russian Federation 2035 (edition of 01.02.2017) /Ministry of Energy of Russia, 78 p.

23. B.G. Saneev, I.Yu. Ivanova, T.F. Tuguzova. Development of renewable energy in Russia's East in the first half of the 21st century against the background of the nationwide trends. Energy policy, Iss.3, pp.66-73. (2016) 